\title{
RISK MANAGEMENT IN BANKING SECTOR: EMPIRICAL DATA \\ FROM COMMERCIAL BANKS IN KOSOVO
}

\section{Isuf QABRATI, MSc. c.}

Prizren University “UKSHIN HOTI, Faculty of Economics, isufqabrati@gmail.com

Article history:
Accepted 11 January 2019
Available online 30 April 2019
Keywords:
Commercial Banks,
Risks,
Liquidity,
Credit,
Equity,
Profitability

\begin{abstract}
A b s t r a c t
Financial institutions are an important source of financial system functioning of a country and include banks, pension funds, insurance companies, microfinance institutions, and so on. While the risk of financial institutions presents their ability to lose, consequently the change of the actual cash flow from the planned one. Among the major risks facing financial institutions are credit risk, market risk, operational risk and liquidity risk. The purpose of this paper is to investigate the risk management in financial institutions by making a survey with the banking sector, which accounts for most of the financial activities. For this reason, eight financial indicators are used to calculate the financial performance of the eight commercial banks involved in the research, which operate in Kosovo, taking into account the last two years of their operation. From the data derived from these indicators, using the One-Way ANOVA analysis, differences between banks were investigated according to their performance. As a result, it has been found that there are significant differences between banks according to liquidity risk, credit risk, equity risk and profitability risk. In addition, a linear regression model was also performed, which shows that the change in the return on equity (ROE) depends almost entirely on the change in the other seven indicators included.
\end{abstract}

\section{Introduction}

Commercial banks represent the largest category of depository institutions and are the most important financial intermediary holding most of the deposits. The depository attribute speaks about the fact that these institutions generate their financial potentials mainly in the form of public deposits, by individuals, businesses and governments (Govori, 2010).

Banks transform the saving of citizens (saver's wealth) into mortgage loans (bank assets). The process can also be described so that "the bank lends the property to the third person for a short term and lends it to another person for a longer term" because it provides long-term loans and finances it by issuing short-term deposits (Mishkin \& Eakins, 2009).

The purpose of this paper is to assess banks' financial risk. Based on literature, it measures the level of this risk to assess whether there are significant differences between banks according to financial risk and as a result to derive a pattern of financial risk regression.

\section{Literature Review}

Risk is defined as uncertainty, that is, as the deviation from an expected outcome (Schroeck, 2002) or some of the more widely discussed definitions of risk include the following: the likelihood an undesirable event will occur; the magnitude of loss from an unexpected event; the probability that "things won't go well"; the effects of an adverse outcome (Apostolik \& Donohue, 2015).

Good risk management involves planning successive activities in identifying, analyzing, assessing, accepting and managing potential risks. The main objective of risk management is to achieve the right balance between risk and return, as well as to reduce the unexpected effects on the bank's financial performance (Economic Bank, 2017).

Risk management is a cornerstone of prudent banking practices. Undoubtedly, all banks in today's volatile environment are facing a number of risks, such as credit risk, liquidity risk, exchange rate risk, market risk and interest rate risk, among others - risks which may threaten the survival and success of the bank. In other words, 
banks are a risk business. For this reason, effective risk management is necessary (Al-Tamimi \& Al-Mazrooei, 2007).

The acceptance and management of financial risk is inherent to the business of banking and banks' roles as financial intermediaries. Risk management as commonly perceived does not mean minimizing risk; rather the goal of risk management is to optimize the risk-reward trade-off (Kanwar, 2005). The ultimate goal of bank management is to increase the institution's earnings and market value. This requires the bank to create a positive difference between the asset return rate and the cost of its obligations. If a negative spread continues, the institution will face bankruptcy. To avoid this disaster, financial managers should carefully evaluate and manage the default risk (Burton, Nesiba, \& Brown, 2015).

Ongore \& Kusa (2013) have studied determinants of financial performance of commercial banks in Kenya, by using bank performance indicators. They have found that capital adequacy, asset quality and management efficiency significantly affect the performance of commercial banks in Kenya. The effect of liquidity on the performance of commercial banks was not strong. The relationship between bank performance and capital adequacy and management efficiency was found to be positive and for asset quality the relationship was negative. This indicates that poor asset quality or high non-performing loans to total asset related to poor bank performance. Thus, it is possible to conclude that banks with high asset quality and low non-performing loan are more profitable than the others. The other bank specific factor liquidity management represented by liquidity ratio was found to have no significant effect on the performance of commercial banks in Kenya. This shows that performance is not as such about keeping high liquid asset; rather it is about asset quality, capital adequacy, efficiency and others. But, this doesn't mean that liquidity status of banks has no effect at all. Rather it means that liquidity has lesser effect on performance of commercial banks in the study period in Kenya.

Wanjohi (2013) has analyzed the effect of financial risk management on the financial performance of commercial banks in Kenya. They have evaluated the current risk management practices of the commercial banks and linked them with the banks' financial performance. Return on Assets (ROA) was averaged for five years (2008-2012) to proxy the banks' financial performance. The study found out that majority of the Kenyan banks were practicing good financial risk management and as a result the financial risk management practices mentioned herein have a positive correlation to the financial performance of commercial banks.

Olamide, Uwalomwa, \& Ranti (2015) examined the relationship between risk management and financial performance of banks of 14listed banks in the financial sector of the Nigerian economy over a period of 6 years (2006-2012). The findings revealed that management of risk does not often translate to positive financial performance of banks. Although effective risk management in financial institutions reduces the occurrence of systemic and economic breakdown, but this does not guarantee increase in the returns on equity.

\section{Methodology}

The purpose of this paper is to make an examination and overall assessment of banks' financial risk in Kosovo, to measure the level of this risk, assess whether there are significant differences between banks according to financial risk and as to derive a financial risk regression model. To accomplish the objective of this research, the study obtained data from banks' annual reports listed in Kosovo's Central Bank. Banks in Kosovo account for approximately $70 \%$ of financial institution activities, that's why this research is focused on banking sector. Considering the limitations of the financial statements of the ten banks operating in Kosovo, the following banks are included in the sample: Raiffeisen Bank, ProCredit Bank, NLB Bank, TEB, National Commercial Bank, Kosovo Economic Bank, Bank for Business and Is Bankasi. From these data, we calculated financial ratios to assess the financial risk of banks and made comparison between banks.

\section{Research Hypotheses:}

According to the literature, banks face different risk, but in general we can speak about liquidity risk, credit risk, equity risk and profitability risk. Therefore, we can propose our hypotheses as following:

H1: There are significant financial differences between banks according to liquidity risk.

$\mathrm{H} 2$ : There are significant financial differences between banks according to credit risk.

H3: There are significant financial differences between banks according to equity risk.

H4: There are significant financial differences between banks according to the risk of profitability.

\subsection{Data Analysis and Research Findings}

The data processed by the bank's annual financial reports were analyzed using the SPSS 23 program. Hypotheses were tested using One-Way ANOVA analysis. 
Table 1. Descriptive Statistics

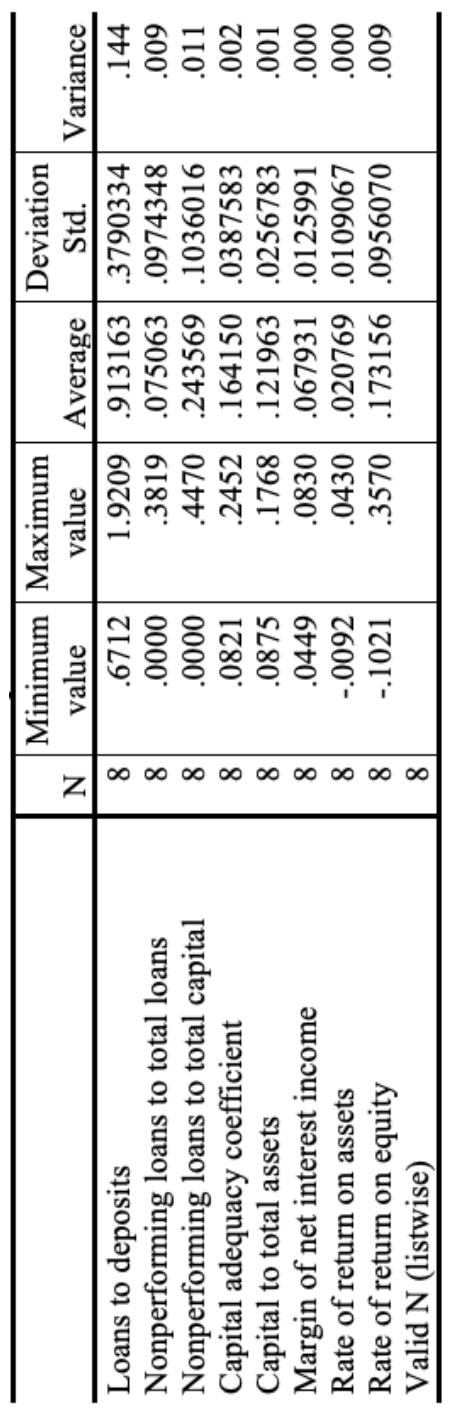

Table 1 gives a summary of the descriptive statistics of the research sample. The sample consists of eight banks and minimum, maximum, average, standard deviation and variance for each financial indicator used are reported.

\subsection{Research Findings}

Below is the test of established research hypotheses.

H1: There are significant financial differences between banks according to liquidity risk.

Table 2: Multiple Comparisons for the Credit to Deposit Coefficient

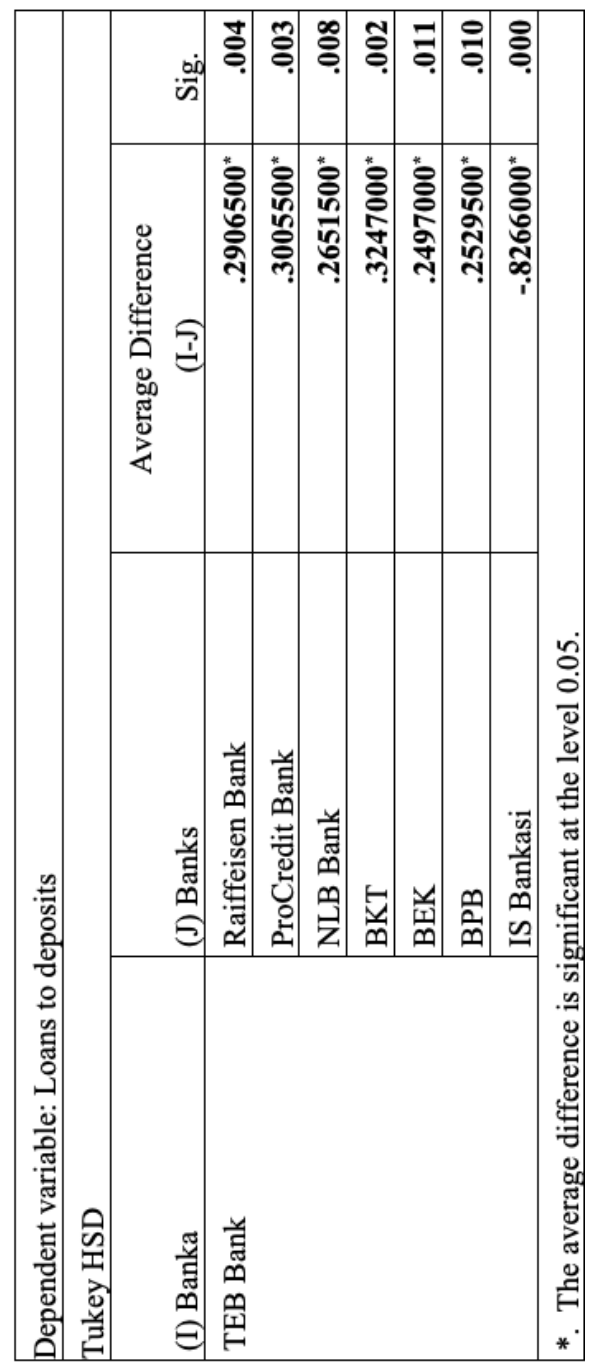

Table 2 presents the results of multiple comparisons between banks. The most plausible difference is the difference between TEB bank and all other banks, Raiffeisen Bank, ProCredit Bank, NLB, BKT, BEK, BPB and IS Bankasi. According to these differences, the TEB Bank has a higher liquidity ratio compared to all other banks, except for the bank IS Bankasi, which has a higher liquidity ratio than the TEB bank. Another important difference that is also apparent is the difference between the IS bank and all other banks, Raiffeisen Bank, ProCredit Bank, NLB, TEB, BKT, BEK and BPB. According to these differences, IS Bankasi has a higher liquidity ratio compared to other commercial banks. As a result, there are significant differences between banks according to the liquidity ratio and from here, H1 hypothesis has been successfully accepted.

H2: There are significant financial differences between banks according to credit risk.

Table 3: Multiple Comparisons for the Credit Risk Report 


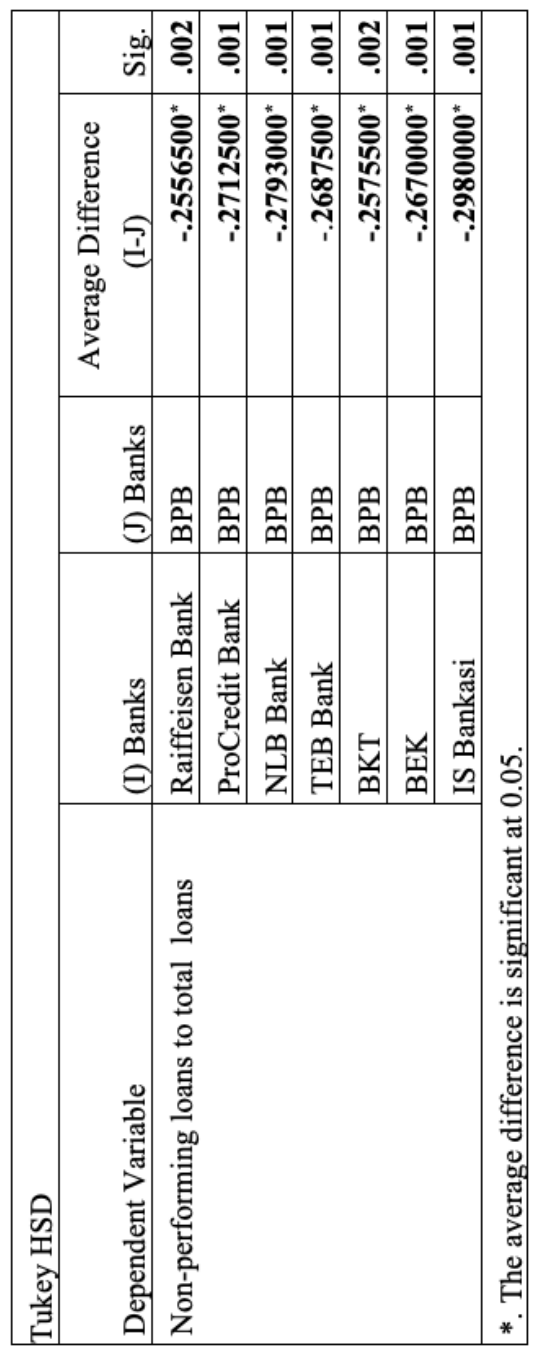

From Table 3, it can be seen that there is a significant statistical difference between BPB bank with all other banks, Raiffeisen Bank, ProCredit Bank, NLB, TEB, BKT, BEK and IS Bankasi. According to these differences, BPB Bank has a higher positive ratio of non-performing loans to total loans compared to other banks. As a result, there are differences between banks according to the credit risk ratio and $\mathbf{H} 2$ hypothesis has been successfully accepted.

Table 4 summarizes the results of the differences between banks and other parts of the table are the jodilities are deleted due to the size of the table. As can be seen from the table, there are differences between Raiffeisen Bank with NLB, BKT, BEK, BPB and IS Bankasi banks according to the capital adequacy coefficient. According to these differences, Raiffeisen Bank has a higher capital adequacy coefficient compared with these banks. In addition, there is also a difference between IS Bankasi with Raiffeisen, ProCredit, NLB and TEB banks. It can be seen that IS Bankasi has a weaker capital adequacy ratio than the abovementioned banks. The last difference according to this coefficient exists between TEB bank and BKT. TEB Bank has a stronger capital adequacy ratio than BKT Bank.

Regarding the capital coefficient to total assets, there are significant differences between TEB bank with BKT, BEK, BPB and IS Bankasi banks. TEB Bank has a higher capital coefficient to total assets compared to these banks. As a result, we conclude that there are significant differences between banks according to the equity ratio and $\mathrm{H3}$ hypothesis has been successfully accepted.

H3: There are significant financial differences between banks according to equity risk.

Table 4: Multiple Comparisons for the Capital Report

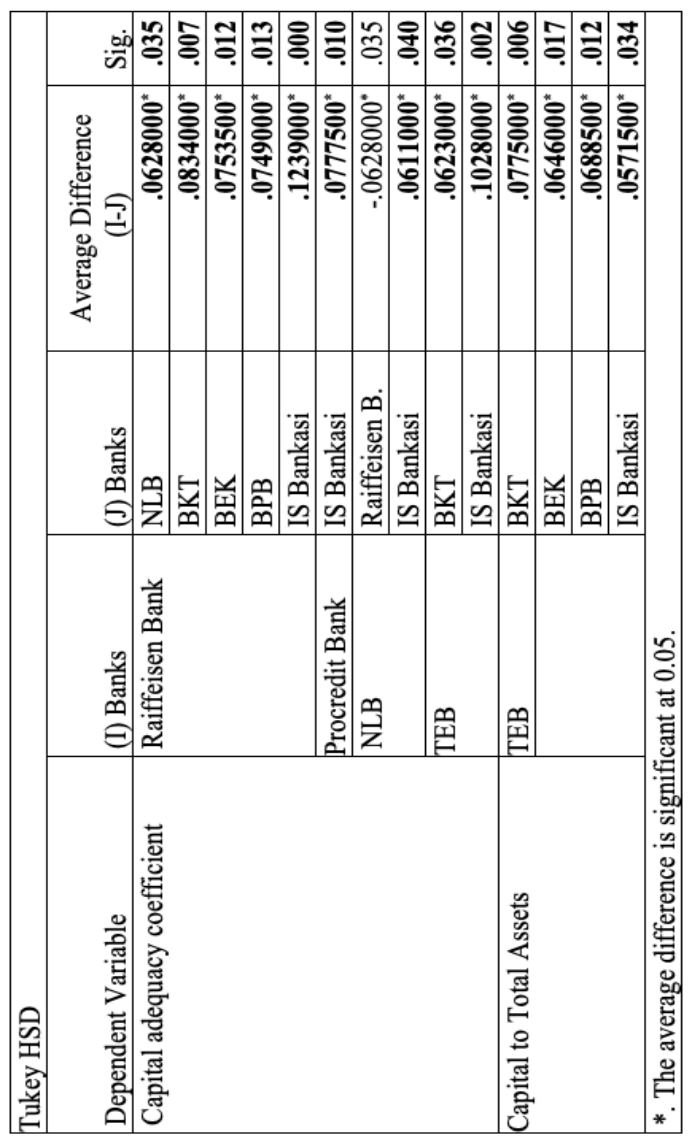

H4: There are significant financial differences between banks according to the risk of profitability. 
Table 5: Multiple Comparisons for the Profitability Report

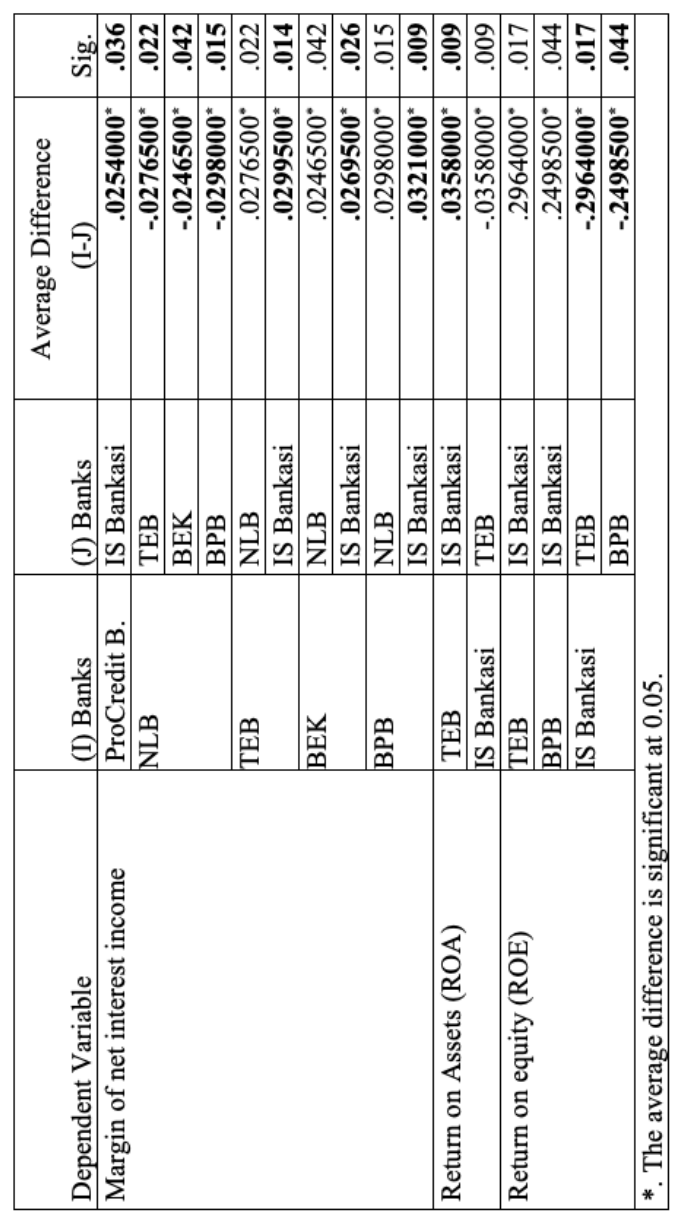

Table 5 shows only the existing differences between banks according to the profitability ratio. Regarding the net interest income ratio coefficient, the most pronounced difference is between NLB bank and TEB, BEK and BPB banks. These differences show that the NLB bank has a lower interest rate net income compared to these banks. Another difference according to this coefficient exists between IS Bankasi with ProCredit, TEB, BEK and BPB banks. These differences point to the fact that IS Bankasi has a lower interest rate net income compared to these banks.

Regarding the rate of return on assets, there is a single significant statistical difference between TEB and IS Bankasi. Accordingly, the TEB Bank has a higher rate of return on assets compared to IS Bankasi.

Meanwhile, according to the rate of return on equity, there are differences between IS Bankasi bank with TEB and BPB banks. From here, IS Bankasi has a lower emphasized ratio of the return on equity compared to these two banks. The other differences between banks according to these coefficients are not significant. As a result, because of these differences, $H 4$ hypothesis is accepted successfully.

\subsection{Linear Regression Model for Banks Risk}

After researching the differences between banks according to financial performance, a regression model for banks was derived, considering the last two years of bank operations. For carrying out regression, the return on equity (ROE) has been taken as a dependent variable and other financial ratios are obtained by independent variables.

Table 6: Summary of the Model ${ }^{\text {b }}$

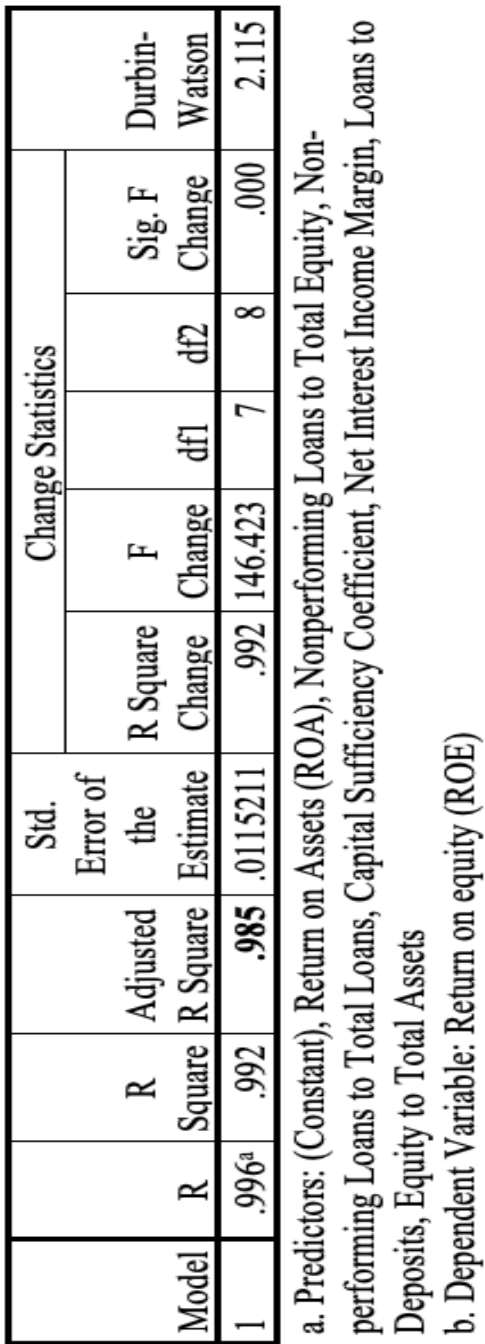

Table 6 presents the most important regression analysis table. The value that is interpreted is the Adjusted R Square value, which indicates that the change in the return on equity varies from $98.5 \%$ to the change in the other independent variables. Thus, independent variables affect $98.5 \%$ at the rate of return on equity, which is quite high.

The following table presents regression coefficients. The linear regression function will be written in this way: 
$R O E=0.075+0.025$ (loans / deposits) +0.002 (nonperforming loans to total loans) +0.020 (nonperforming loans to total capital) +0.130 (capital adequacy) - 1.490 (total capital / assets) +0.089 of net interest income $)+10,802($ ROA $)$.

Table 7: Regression coefficients ${ }^{\mathrm{a}}$

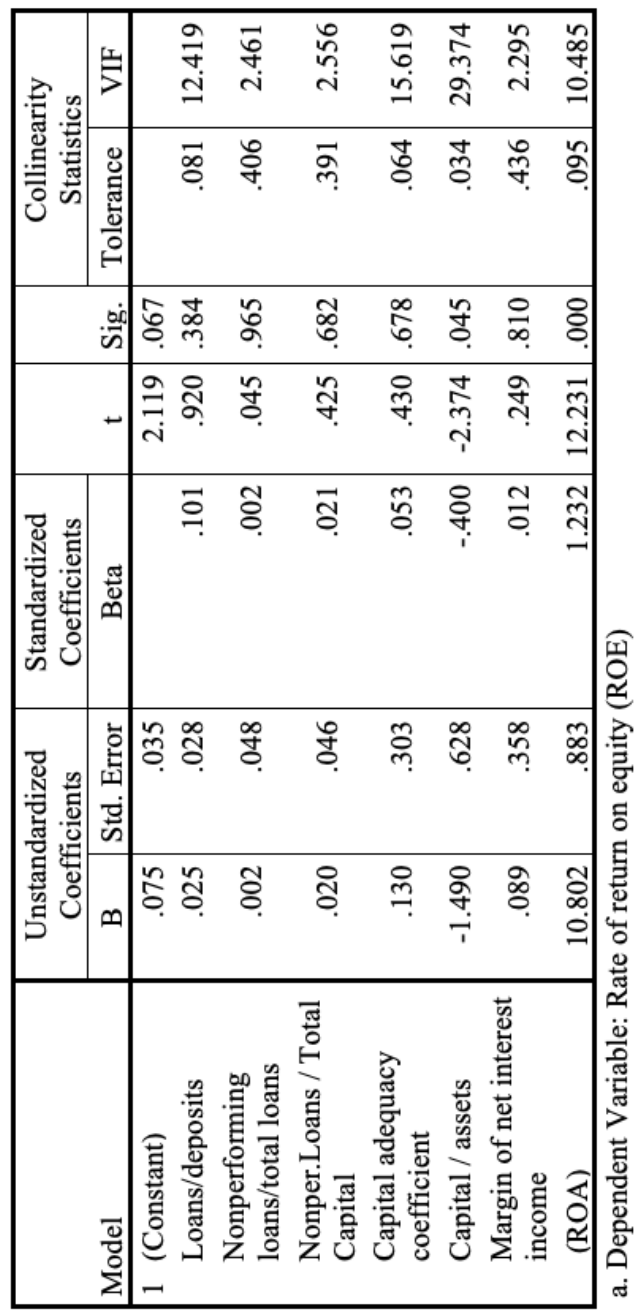

The constant value is 0.075 which indicates that when all these indicators are taken constant, the banks will have a return rate of 0.075 units. With the growth of a unit in the loan-to-deposit ratio, ROE will increase by 0.025 units; with the growth of a unit in non-performing loans to total loans, ROE will increase to 0.002 ; with the increase of a unit in non-performing loans to total equity, ROE will increase by 0.020 ; with the increase of a unit in the capital adequacy ratio, ROE will increase by 0,130 units, with the increase of a unit in the capital coefficient to total assets, the ROE will be reduced by 1,490 units, with the increase of a unit in the margin of net interest income, ROE will increase to 0.089 and with a unit increase in return on assets, ROE will increase to 10.802 units

\section{Conclusion and Further Discussion}

Financial risk indicates the potential for a bank's loss. The aim of this paper was to make a general review and assessment of banks' financial risk, measure the level of this risk, assess whether there are significant differences between banks according to financial risk and as a result to derive a risk regression model financial. For risk assessment, research has been conducted with commercial banks operating in Kosovo, as a result of higher activity in the financial sector. The banks that were involved in the research in general showed good financial performance and had a satisfactory level of financial indicators, thus reflecting the financial health of the banking sector.

From the analysis conducted it was found that IS Bankasi has a higher liquidity ratio compared to all other commercial banks. Regarding the credit aspect, BPB Bank has a higher positive ratio of non-performing loans to total loans compared to other banks. According to capital adequacy, Raiffeisen Bank has a higher capital adequacy coefficient compared with NLB, BKT, BEK, BPB and IS Bankasi banks. The profit-based analysis showed that the NLB bank has a lower interest income net interest rate compared to the TEB, BEK and BPB banks. Based on the return on assets, there was a single difference that showed that the TEB bank has a higher rate of return on assets compared to IS Bankasi. Meanwhile, according to the rate of return on equity, IS Bankasi has a lower emphasis on the rate of return on equity compared with TEB and BPB banks.

Banks should be careful to keep their business stable and also comply with the minimum requirements of the CBK parameters. From the reviewed banks, in terms of liquidity, they must always have sufficient liquid assets to meet the needs of their own depositors (clients) within a day and be able to pay their own operating expenses. Based on asset quality indicators, given that banks maintain a reserve for loan losses, this reserve should result in a lower level, as the high level of these reserves for the bank presents an increased level of risk. It is preferred that banks have the necessary capital, which should be in an acceptable proportion with risk exposure. Regarding the profits, since the indicators were in a satisfactory level in general then the factors that have influenced not only the profit trend but also the sustainability of these profits should be looked at. Sustained gains absorb current and potential lending losses, which also contributes to increasing public confidence in the bank and are also needed for a balanced financial structure. Bank financial managers should take into account all the reviewed financial indicators. Particularly be careful in providing a higher rate of return on equity as this is a main objective of management, therefore increase shareholder wealth. The higher the coefficient, the higher the return on equity 
(ROE). But managers need to be attentive to the resources of a high ROE, because an increase in this indicator as a result of the increase in the leverage ratio (bank debt relief) implies that financial leverage, namely the risk of insolvency or bank failure has increased. Further more, this research provides important information for those who will research this topic later in Kosovo. Future research may also include other operational indicators and then explore relationships between them and make comparisons between banks. Another regression model based on these financial and operational indicators can also be extracted.

\section{References}

1. Al-Tamimi, H. A., \& Al-Mazrooei, M. F. (2007). Banks' risk management: a comparison study of UAE national and foreign banks. The Journal of Risk Finance, 394-409.

2. Apostolik, R., \& Donohue, C. (2015). Foundations of Financial Risk. New Jersey: John Wiley \& Sons, Inc.

3. Burton, M., Nesiba, R., \& Brown, B. (2015). An Introduction to Financial Markets and Institutions. New York: Routledge.

4. Economic Bank, K. (2017). Annual Report of the Economic Bank. Retrieved August 8, 2018, from Economic Bank Website: http://www.bekonomike.com

5. Govori, F. (2010). Financë. Prishtinë: Instituti për Financa dhe Menaxhment.
6. Kanwar, A. A. (2005). Risk Management for Banks PAF-Karachi Institute of Economics and Technology, 1(1).

7. Mishkin, F., \& Eakins, S. (2009). Tregjet dhe Institucionet Financiare - Pjesa II. Prishtinë: Kolegji Victory.

8. Olamide, O., Uwalomwa, U., \& Ranti, U. O. (2015). The Effect of Risk Management on Bank's Financial Performance in Nigeria. IBIMA Publishing Journal of Accounting and Auditing: Research \& Practice, Vol. 2015 (2015), 1-7.

9. Olamide, O., Uwalomwa, U., \& Ranti, U. O. (2015). The Effect of Risk Management on Bank's Financial Performance in Nigeria. Journal of Accounting and Auditing: Research \& Practice, 7.

10. Ongore, V. O., \& Kusa, G. B. (2013). Determinants of Financial Performance of Commercial Banks in Kenya. International Journal of Economics and Financial Issues, 3(1), 237-252.

11. Ongore, V. O., \& Kusa, G. B. (2013). Determinants of Financial Performance of Commercial Banks in Kenya. International Journal of Economics and Financial Issues, 237-252.

12. Schroeck, G. (2002). Risk Management and Value Creation in Financial Institutions. New Jersey: John Wiley \& Sons, Inc.

13. Wanjohi, J. G. (2013). The effect of financial risk management on the financial performance of commercial banks in Kenya. University of Nairobi. 